\title{
Towards optimizing prostate tissue retrieval following holmium laser enucleation of the prostate (HoLEP): Assessment of two morcellators and review of literature
}

\author{
Ahmed M. Elshal, MD; Ramy Mekkawy, MD; Mahmoud Laymon, MD; Ahmed El-Assmy, MD; \\ Ahmed R. El-Nahas, MD
}

Urology and Nephrology Center, Mansoura University, Mansoura, Dakahlia Governorate, Egypt

Cite as: Can Urol Assoc J 2015;9(9-10):E618-25. http://dx.doi.org/10.5489/cuai.3035

Published online September 9, 2015.

\section{Abstract}

Introduction: We assess different approaches to retrieve the enucleated adenoma after transurethral enucleation of the prostate, particularly using the holmium laser.

Methods: A retrospective review through our prospectively maintained database was performed looking for safety and efficacy of two morcellators. The enucleation phase of the holmium laser enucleation of the prostate (HoLEP) was classically performed followed by retrieval of the intravesical adenoma using either the Piranha (Wolf Inc., Knittlingen, Germany) or VersaCut (Lumenis) morcellator. A PubMed-MEDLINE search was conducted for all transurethral enucleation procedures and relevant data regarding methods of prostate tissue retrieval were extracted.

Results: Strictly limiting the study to 3 reusable blades with each morcellator, we performed 67 and 55 consecutive procedures with Piranha and VersaCut, respectively. There was no significant difference between the two morcellators regarding perioperative complications, apart from 5 bladder mucosal injuries with the VersaCut (9\%). Furthermore, there were similar retrieved tissue weight, mechanical problems-rate, catheter-time and hospital-stay in both morcellators. However, the Piranha morcellator needed significantly less morcellation-time, needed to use cold loop to remove non-morcellated pieces and to score the adenoma by laser for better bite of the adenoma, and had a higher median morcellation-rate 6.2 (rate: $2.8-12$ ) g/min.

Despite little reporting on morcellation, we had data on the tissue retrieval rate $(2.6$ to $6.5 \mathrm{~g} / \mathrm{min}$ with Piranha and 1.9 to $11 \mathrm{~g} / \mathrm{min}$ with VersaCut. Furthermore, bladder mucosal injury was reported in $1.4 \%$ and 0.7 to $5.7 \%$ with Piranha and VersaCut, respectively; bladder perforation with VersaCut was experienced in about 0.1 to $1.5 \%$ of patients. Our study is limited by its non-randomization. Conclusion: The Piranha morcellator was the most efficient and safe way to retrieve tissue after a transurethral enucleation of a prostate adenoma.

\section{Introduction}

With advancements in the treatment of benign prostatic hyperplasia $(\mathrm{BPH})$, patients are now older and have larger prostates at surgery. In these patients, transurethral enucleation is superior to other techniques. ${ }^{1}$

Different kinds of energy have been used in the enucleation procedure, including holmium $\mathrm{YAG}^{2}{ }^{2}$ thulium, ${ }^{3}$ Greenlight laser $(532 \mathrm{~nm}){ }^{4}$ and plasma kinetic energy, ${ }^{5}$ ending by completely or partially detaching the intravesical adenoma. However, the techniques of prostate tissue retrieval, particularly intravesical morcellation of prostatic adenoma, are poorly evaluated.

The transurethral morcellation of intravesical prostate adenoma is a tedious procedure. Many difficulties could be encountered, such as impaired visibility with minor bleeding, variable consistency of the adenoma, and malfunction of reusable blades, especially with large prostates. Furthermore, the morcellation process might come after lengthy enucleation procedure that might oblige the surgeon to postpone it to another session (secondary morcellation). ${ }^{6}$

Transurethral enucleation of the prostate adenoma using holmium laser (HoLEP) has been extensively studied over the past 15 years. However, safety and efficacy of different approaches used to retrieve the enucleated adenoma have not been studied. Since the invention of the mechanical tissue morcellator in 1996, ${ }^{7}$ tissue morcellators for different endoscopic surgical procedures have significantly evolved, including those used for transurethral morcellation of intravesical prostate adenoma. There are two popular tissue morcellators. The main differences between them are the type of movement of the cutting blades (guillotine vs. oscillation) and shape of the blade (non-toothed vs. toothed) in the VersaCut (Lumenis Inc.) and Piranha (Wolf Inc., Knittlingen, Germany) morcellators, respectively. Alternatives to tissue morcellators are the mushroom technique ${ }^{8}$ and mini-laparotomy suprapubic extraction of the enucleated adenoma. ${ }^{9}$ 
In this study, we used the Versacut and Piranha morcellators for prostate tissue retrieval during HoLEP. We also reviewed the relevant literature.

\section{Methods}

After obtaining institutional review board approval, we reviewed the data of 122 consecutive HoLEP procedures to assess tissue retrieval between November 2013 and October 2014. A single surgeon (AME), with experience in the HoLEP procedure with at least 30 procedures of morcellation using either morcellator, performed the procedures. This comparative study was initiated based on local administrative request to purchase another morcellator.

Patients were admitted for BPH surgery when they had refractory lower urinary tract symptoms and failed medical treatment or if they had an indwelling catheter due to urine retention and failed trial of voiding without a catheter. Patients with a history of previous prostate surgery or with diagnosed prostate cancer were not included in the analysis.

\section{Intervention}

A 100W Holmium: YAG laser (Versapulse, Lumenis Inc., Santa Clara, CA) and a 550-um end-firing flexible fibre (SlimLineTM 550, Lumenis Inc.) were used. Continuous flow 26Fr resectoscope (Karl Storz, Tuebingen, Germany) was used for all procedures; a connecting piece was used to adapt a rigid indirect long nephroscope (Karl Storz) with a 5-mm working channel through which the morcellator blade passed. Double irrigation sets were used connected to both inflow and outflow channels of the scope. The enucleation phase of HoLEP was performed as previously described. ${ }^{2}$ Retrieval of the prostate adenoma was performed by trans-

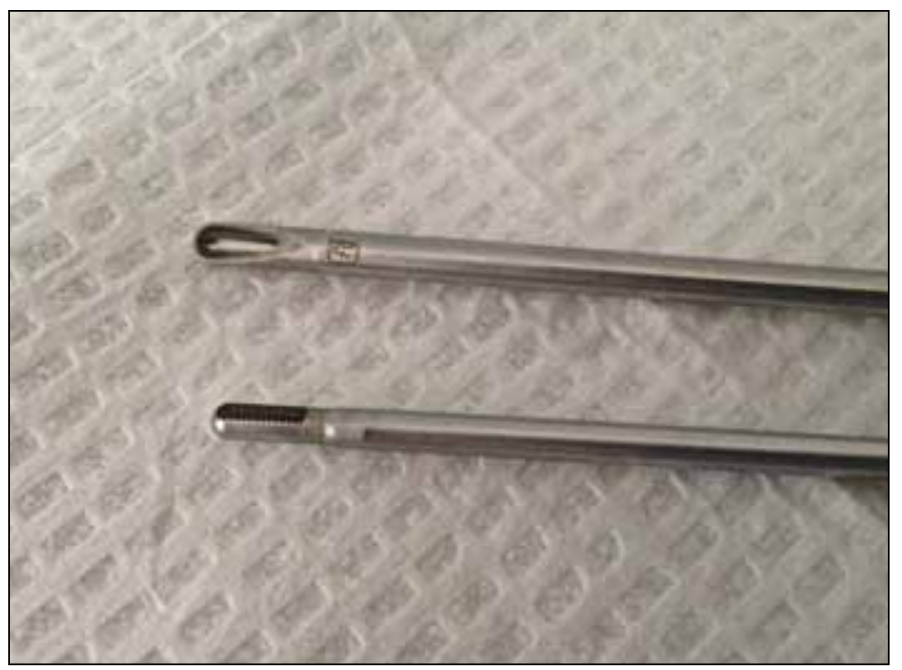

Fig. 1a. Blade of pirnha morcellator. urethral morcellation using either Piranha morcellator (Fig. 1, parts $A$ and $C$ ) or the VersaCut (Fig. 1, parts B and D). The morcellator blade was introduced just inside the bladder neck with the blades facing up; the initial suction brings the adenoma over the tip of the blades after which the cutting starts. The blades and the adenoma are kept away from the bladder mucosa to avoid any laceration.

Between November 2013 and March 2014, we consecutively performed 55 procedures with the VersaCut morcellator, during which 3 new reusable blades were consumed. Between April 2014 and October 2014, we consecutively performed 67 procedures with the Piranha morcellator, during which 3 new reusable blades were consumed. We tallied every case and marked every single blade. Moreover, all peri-procedural parameters were recorded and the surgeon determined whether any blades were non-usable.

All morcellation auxiliary procedures were recorded. Auxiliary procedures included the use of a crown loop (toothed cold loop, Fig. 1, parts E and F) to extract nonmorcellated pieces or the use of a laser to score hardly bitten adenomas by the blade. Postoperatively, a 22Fr tri-way urethral catheter was fixed. Most patients were discharged the next day.

\section{Primary outcome measures}

Operative efficacy parameters were reported and compared. Efficacy parameters included the time and rate of tissue retrieval procedure, weight of the tissue retrieved and overall operative time. Time of tissue retrieval was defined as the time from introduction of the morcellator blade to the bladder until extraction of the last piece of the prostatic adenoma. The rate of retrieval was calculated by dividing the weight of the prostate specimen by the time needed for retrieval.

\section{Secondary outcome measures}

Perioperative complications (safety) were reported and compared. Morcellation-related complications, namely bladder injury and peri-procedural bleeding, were com-

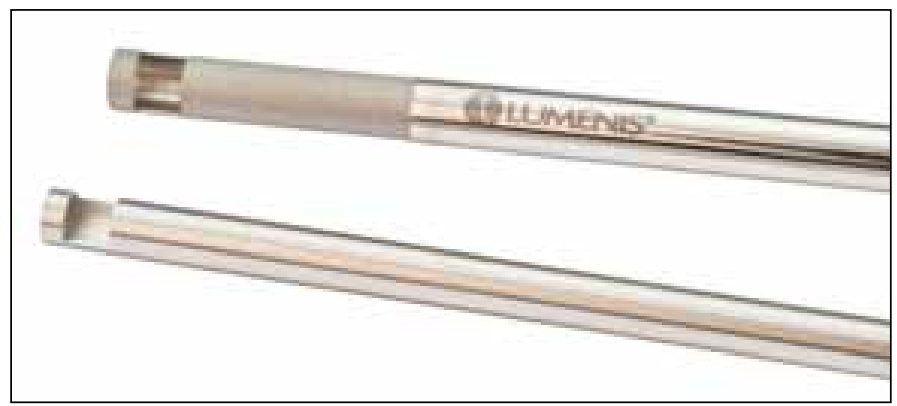

Fig. $\mathbf{1 b}$. Blade of versacut morcellator. 


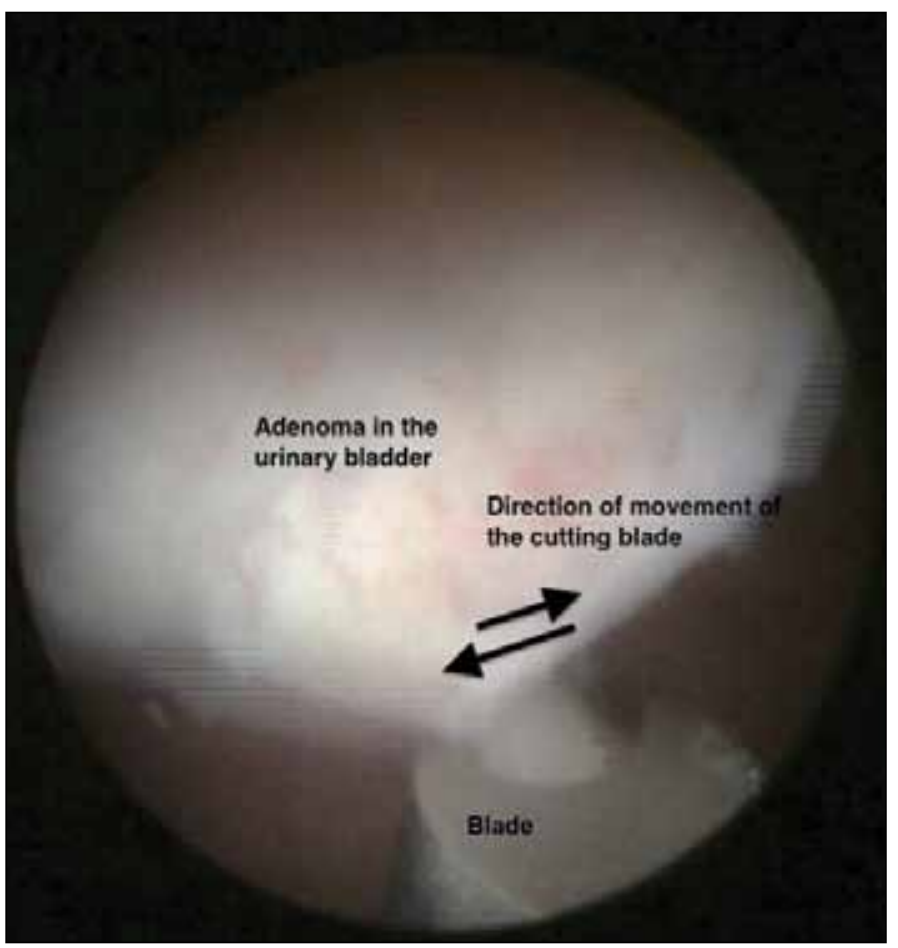

Fig. 1c. Blade of pirnha morcellator in action.

pared. Hospital stay and catheter time were recorded and compared.

\section{Statistical analysis}

Data analysis was conducted using the commercially available Statistical Package for Social Sciences (SPSS 20 for Mac, SAS Institute, Cary, NC). Results were compared between study groups using the Chi-square and Fisher's exact tests for categorical variables and the independent samples t-test and Mann-Whitney U-test for quantitative variables as appropriate. Using post-hoc analysis for the studied sample, considering type 1 statistical error less than 0.05 , effect size of 0.6

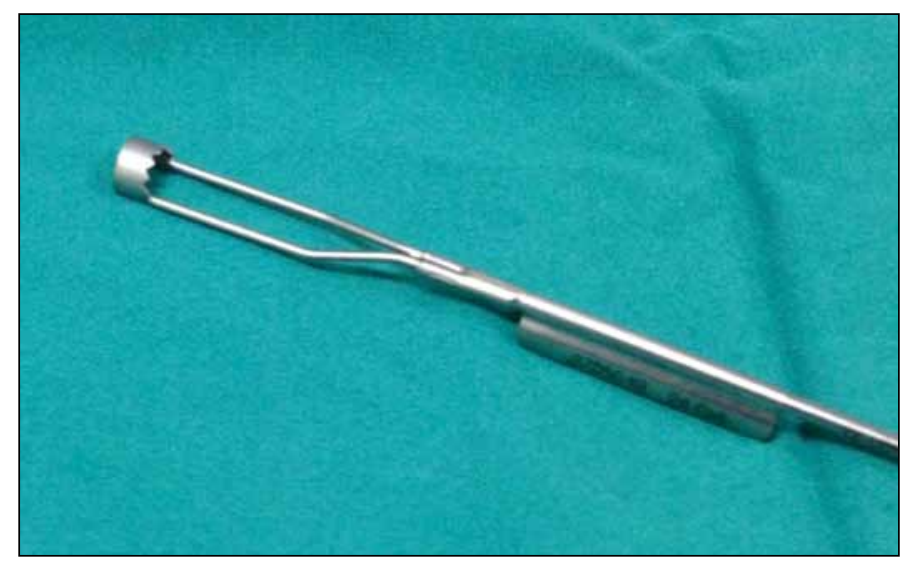

Fig. 1e. Crown loop.

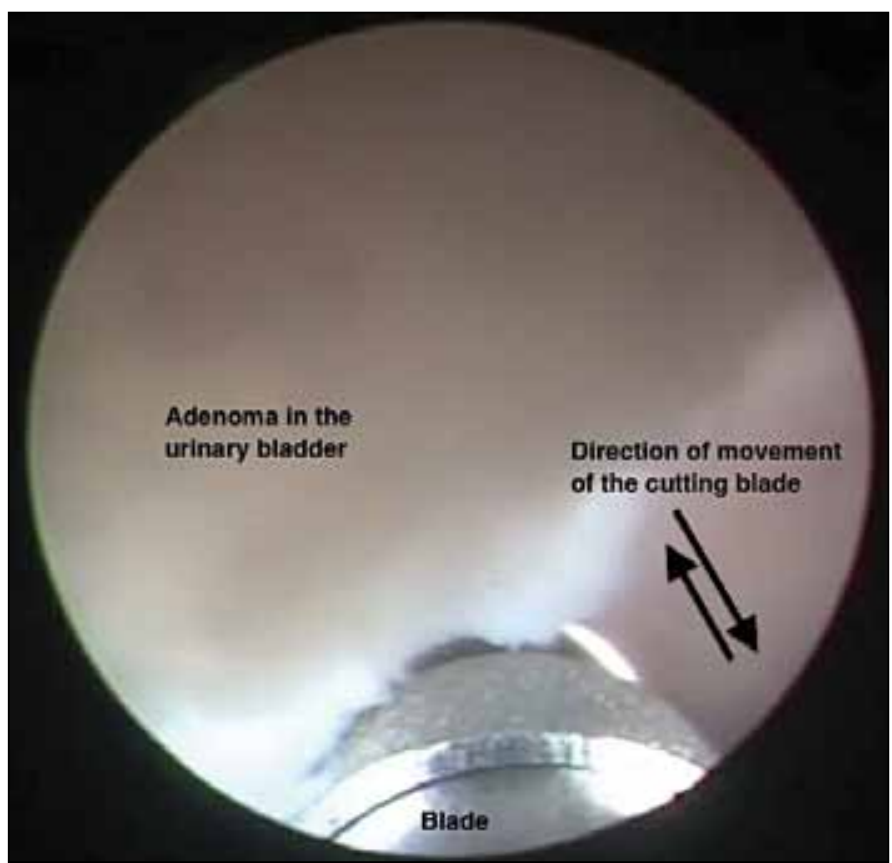

Fig. 1d. Blade of versacut morcellator in action.

for the tissue retrieval rate and two-tailed significance, we achieved a computed power of $90 \%$.

\section{Review of literature}

We searched PubMed-MEDLINE for English-based literature using medical subject headings including benign prostatic hyperplasia (BPH), enlargement (BPE), and obstruction (BPO); minimal invasive surgery; and the specific MIST and TURP name looking for all transurethral prostate enucleation techniques. Reference lists of all depicted articles were reviewed for relevant reports. Different articles based on the same patient cohort with different follow-up duration and/or outcome measures were considered a single study, and all relevant data regarding methods of prostate tissue retrieval were extracted.

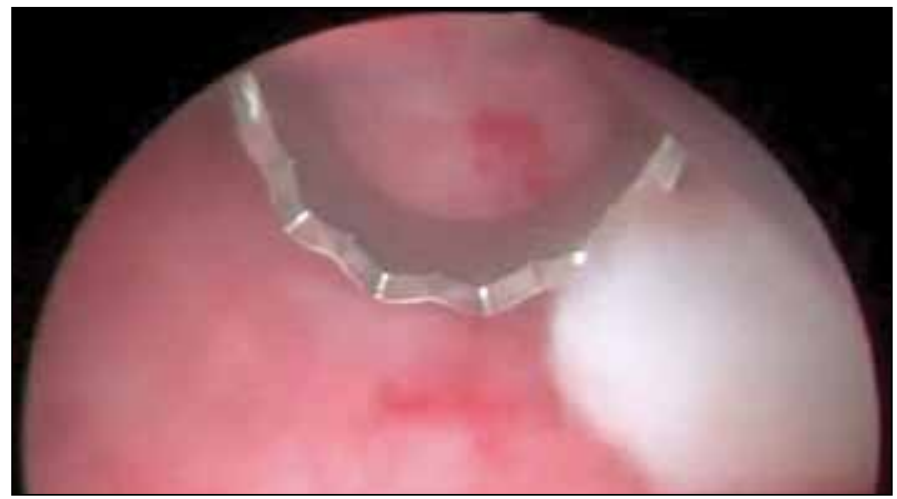

Fig. 1f. Crown loop in the bladder to extract non morcellated adenomas. 


\begin{tabular}{|c|c|c|c|}
\hline & Piranha¥ & VersaCut $†$ & $n$ ulu \\
\hline No. procedures & 67 & 55 & $\rho$ value \\
\hline $\begin{array}{l}\text { Median, range tissue } \\
\text { retrieval time (min) }\end{array}$ & $20(5: 30)$ & $25(5: 70)$ & 0.04 \\
\hline $\begin{array}{l}\text { Histopathology; median, } \\
\text { range of weight of } \\
\text { specimen }(\mathrm{g})\end{array}$ & $67(23: 230)$ & $62(14: 189)$ & 0.07 \\
\hline $\mathrm{BPH}(\%)$ & $65(97)$ & $50(92)$ & 0.34 \\
\hline BPH with prostatitis (\%) & - & $2(3.6)$ & \\
\hline $\begin{array}{l}\text { BPH with focal prostate } \\
\text { cancer }(\%)\end{array}$ & $2(3)$ & $3(5.4)$ & \\
\hline $\begin{array}{l}\text { Median, range of tissue } \\
\text { retrieval rate }(\mathrm{g} / \mathrm{min}) \\
\text { [specimen weight/retrieval } \\
\text { time] }\end{array}$ & $6.2(2.8: 12)$ & $2.13(0.46: 7)$ & 0.00 \\
\hline $\begin{array}{l}\text { Use of crown loop* } \\
\text { for extraction of non- } \\
\text { morcellated parts (\%) }\end{array}$ & $4(5.9)$ & $17(30.9)$ & 0.00 \\
\hline $\begin{array}{l}\text { Laser scoring of the } \\
\text { adenoma to ease bite by } \\
\text { the blade }(\%)\end{array}$ & - & 7 & 0.00 \\
\hline $\begin{array}{l}\text { Intraoperative morcellator } \\
\text { mechanical problems }(\%)\end{array}$ & $7(10.4)$ & $2(3.6)$ & 0.2 \\
\hline $\begin{array}{l}\text { Median, range of } \\
\text { catheterization time (days) }\end{array}$ & $1(1: 5)$ & $1(1: 3)$ & 0.3 \\
\hline $\begin{array}{l}\text { Median, range of Hospital } \\
\text { stay (days) }\end{array}$ & $1(1: 3)$ & $1(1: 4)$ & 0.08 \\
\hline
\end{tabular}

*Crown loop; toothed cold loop. BPH: benign prostatic hyperplasia; NA: not applicable.

¥Piranha, Wolf Inc., Knittlingen, Germany; †VersaCut, Lumenis.

\section{Results}

Following Holmium laser-assisted enucleation of the prostate adenoma, the Piranha morcellator was used in 67 procedures and the VersaCut morcellator in 55 procedures. The preoperative prostate size was similar in both morcellators (median [range] transurethral resection of the prostate estimated prostate size was 130 [ranage: 59-295] and 114 [range: 46-345] $\mathrm{mL}$ with Piranha and VersaCut morcellators, respectively, $p=0.1$ ). Histopathologic findings of the retrieved prostate tissues were not different between the two morcellators. Significantly more prostate tissue retrieval time and need of morcellation auxiliary procedures were reported with the VersaCut morcellator (Table 1).

The median tissue retrieval rate was 6.2 (range: 2.8-12) and $2.13(0.46-7) \mathrm{g} / \mathrm{min}$ with the Piranha and VersaCut morcellators, respectively $(p=0.001)$. Similar retrieved tissue weight and catheter time were reported in both morcellators (Table 1).

The median number of procedures done per blade was 22 (range: $20-25)$ and $18(17-20)$ with the Piranha and VersaCut morcellators, respectively $(p=0.01)$. The median number of grams of prostate tissue retrieved per blade was 1499 (range: 1388-1539) and 943 (833-1248) with the Piranha and VersaCut morcellators, respectively $(p=0.04)$.

\begin{tabular}{|c|c|c|c|}
\hline & Piranha¥ & VersaCut $†$ & $p$ value \\
\hline No. procedures & 67 & 55 & \\
\hline $\begin{array}{l}\text { Bleeding necessitating post } \\
\text { retrieval hemostasis (\%) }\end{array}$ & $1(1.4)$ & $5(9)$ & 0.06 \\
\hline $\begin{array}{l}\text { Median, range of } \\
\text { Hemoglobin deficit* }(\mathrm{g} / \mathrm{dL})\end{array}$ & $\begin{array}{c}1.2 \\
(0.1: 4.8)\end{array}$ & $1.5(0.1: 3.7)$ & 0.2 \\
\hline $\begin{array}{l}\text { Median, range of Hematocrit } \\
\text { value deficit* }(\%)\end{array}$ & $\begin{array}{c}4.3 \\
(-1.6: 14.7)\end{array}$ & $\begin{array}{c}4.3 \\
(-7.9: 20.2)\end{array}$ & 0.8 \\
\hline $\begin{array}{l}\text { Median, range of Blood } \\
\text { sodium deficit* }(\mathrm{mmol} / \mathrm{L})\end{array}$ & $1.5(1: 2.1)$ & $3(-8.7: 11.6)$ & 0.7 \\
\hline \multicolumn{4}{|l|}{ Bladder injury (\%) } \\
\hline Bladder mucosal injury & - & $5(9)$ & 0.01 \\
\hline Bladder perforation & - & - & \\
\hline Postoperative hematuria (\%) & $4(2.9)$ & $2(3.6)$ & 0.19 \\
\hline
\end{tabular}

There was no significant difference between the two morcellators regarding perioperative biochemical changes and complications, apart from 5 bladder mucosal injuries in the VersaCut group (9\%) (Table 2).

Table 3 summarizes the tissue retrieval approaches used in contemporary series of different transurethral enucleation procedures. Data on preoperative prostate size, retrieved prostate weight, rate of tissue retrieval and possible complications related to the procedure of retrieval namely bleeding and bladder injury were tallied. Furthermore, findings of incidental prostate cancer and history of prior prostate surgery were depicted for possible impact on prostate tissue consistency. ${ }^{3-6,8,10-27}$

\section{Discussion}

The transurethral enucleation of prostate adenoma carries the advantage of doing an anatomical based de-obstruction, which further to being complete is safer by tackling the vascular supply once it goes to the adenoma. Many competing techniques using different energy sources (electric and different lasers) to accomplish the enucleation procedure have been reported..$^{2-5}$ However, retrieval of the adenoma after transurethral enucleation remains poorly evaluated. Transurethral resection of partially detached adenoma is not advantageous as it can induce more risk of bleeding, impaired visibility and is time consuming, especially for large prostates where the transurethral enucleation is superior to other minimally invasive surgeries.

Morcellation of intravesical adenoma is currently the standard procedure following most transurethral enucleation procedures; however it is poorly evaluated. It is not complication-free and might require the surgeon to stage the procedure (secondary morcellation due to bleeding or blade malfunction). ${ }^{6}$

In our current study, we presented the current viable approaches used to retrieve the enucleated prostate ade- 


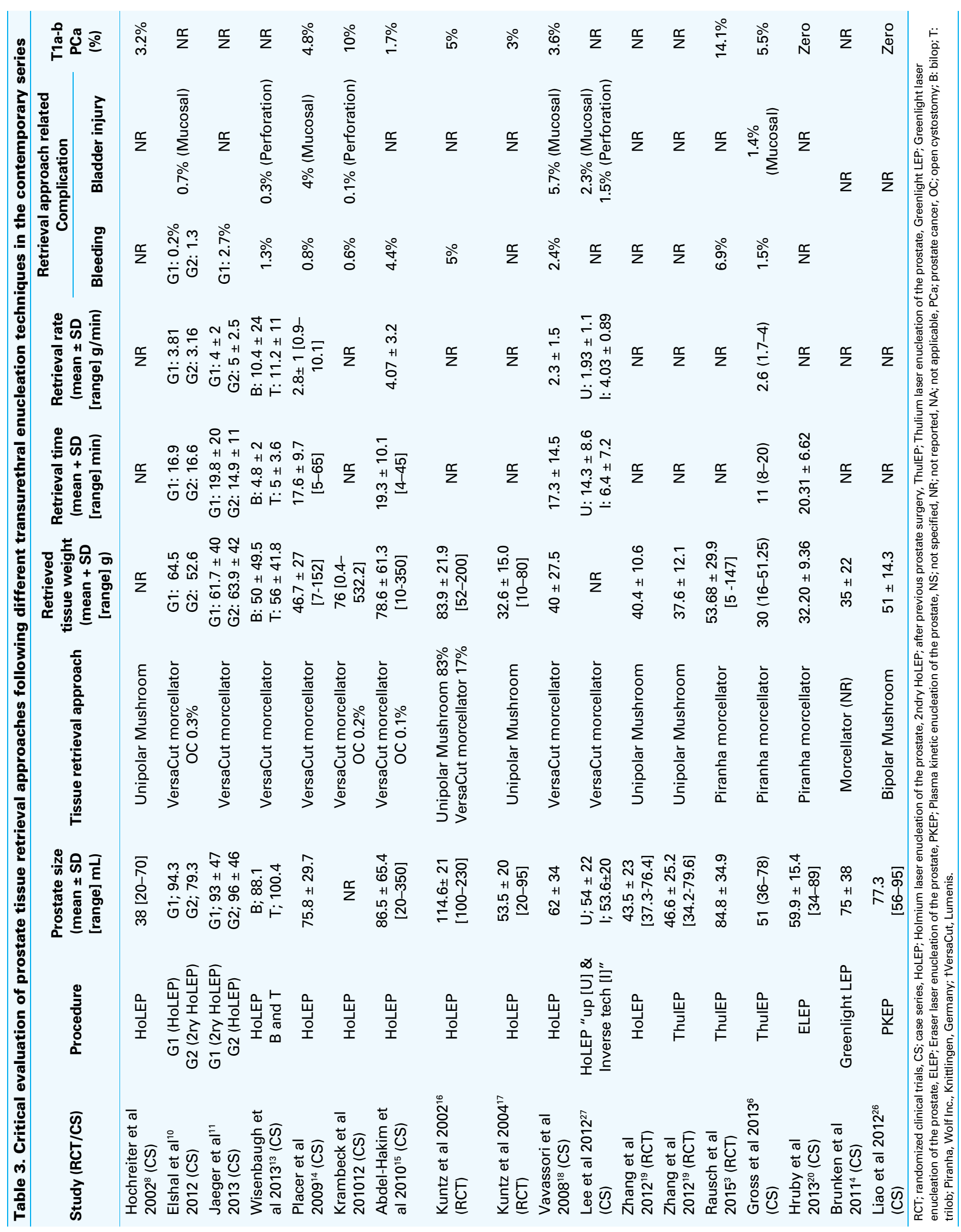


noma following holmium laser enucleation. We compared safety and efficacy of two commercially available morcellators that have not been previously clinically compared. A single surgeon, with HoLEP experience with at least 30 morcellations using either morcellator, performed the procedures. A minimum of 20 cases are required to achieve morcellation efficiency. ${ }^{28}$

In an ex-vivo study, the efficiency of different morcellators were assessed. The Piranha morcellated 20 (range: 19.3-21.4) $\mathrm{g} / \mathrm{min}$, the VersaCut 10.8 (range: 8.2-13.1) $\mathrm{g} / \mathrm{min}$, Karl Storz prototype 9.8 (range: $7.9-10.76$ ) $\mathrm{g} / \mathrm{min}$, and another Wolf prototype 38.6 (35.3-42.9) g/min. ${ }^{29}$ Another ex-vivo study looking at different efficiency parameters of the Piranha and VersaCut morcellators revealed similar suction power parameters (20.4 and $22.2 \mathrm{~mL} / \mathrm{s}$, respectively). Morcellating powers were (example with baked chicken meat) 2.5 and $6 \mathrm{~g} / \mathrm{min}$ with Piranha and VersaCut, respectively. ${ }^{30}$

In the current study, the median rate of tissue retrieval was 6.2 (range: 2.8-12) and 2.13 (range: 0.46-7) g/min with Piranha and VersaCut morcellators, respectively. The literature demonstrated tissue retrieval rates of 2.6 to 6.5 and 1.9 to $11 \mathrm{~g} / \mathrm{min}$ with Piranha and VersaCut morcellators, respectively (Table 3); however, there is little data on the details of morcellation in clinical reports of transurethral enucleation procedures. The safety of morcellator is a crucial part of the assessment in our current study; superficial bladder mucosal injury was reported in $9 \%$ of procedures with the VersaCut morcellator. Superficial bladder mucosal injury was reported in $1.4 \%$ and 0.7 to $5.7 \%$ with Piranha and VersaCut morcellators, respectively; there were bladder perforations with the VersaCut morcellator (range: $0.1-1.5 \%$ ) (Table 3). In their ex-vivo study, Cornu and colleagues showed that the blade of the Pirhana morcellator was under visual control, whereas the distal part of the cutting blade was out of vision control with the VersaCut. ${ }^{30}$

The efficiency of tissue retrieval by a morcellator is a sum of multiple variables, including prostate tissue consistency, suction power, and morcellator blade. Prior prostate surgery and histopathological features of the adenoma probably affect prostate tissue consistency.

Other non-morcellation approaches have been used in many of the reported transurethral enucleation techniques, as a routine practice (like using mushroom technique after most bipolar enucleation techniques ${ }^{5,23,26}$ and, to a lesser extent, after HoLEP $8,16,17$ ) or occasional in cases of morcellator malfunction or for exceptionally huge adenomas where some surgeons perform an open cystostomy for adenoma extraction. ${ }^{10}$

The morcellator action is to cut and suck. Most of mechanical problems reported in this study were related to suction. In the Piranha morcellator, suction depends on creating negative pressure within a vacuum bottle. Problems 
occurred secondary to leak of negative pressure from the vacuum bottle/ tubing set. This requires the surgeon to stop to recreate the required negative pressure. In the VersaCut morcellator, suction depends on a high-suction roller pump; obstruction of the tubing set with large tissue piece causes malfunction of the pump and significantly reduces suction power. This also requires the surgeon to stop and reverse direction of flow for a while to clean the tubing set.

Lastly, regarding the technique of transurethral morcellation, we used the conventional upward technique. A modification of the technique to increase morcellation efficiency and to lessen the incidence of bladder injury is called "the inverse technique." ${ }^{27}$ It entails sucking the adenoma toward the blades then inversely rotating the nephroscope and the blades, with the blade openings pointing inferior toward the bladder and superior to the prostate tissue. Lee and colleagues reported a higher rate of tissue retrieval with their technique using the VersaCut morcellator. ${ }^{27}$ Superficial $(7.1 \%$ and $0.9 \%)$ and deep bladder injuries in $5.9 \%$ and $0.3 \%$ ) were reported in conventional and inverse techniques, respectively (Table 3 ).

Our study has its limitations. In terms of evidence, this study lacks randomization. However, we found that randomization was not practical for an in depth evaluation of all aspects of morcellation, including reusable blade efficiency (e.g., surgeons prefer using new or minimally used blades when tackling significantly large glands). So, we assigned 3 blades for each morcellator group for the study, with careful reporting of all peri-procedure parameters.

\section{Conclusion}

Morcellation with the Piranha morcellator was the most efficient and safe way to retrieve tissue following transurethral enucleation of prostate adenoma during BPH treatment. Detailed reporting of the morcellation step is recommended in any report of a transurethral enucleation technique.

Competing interests: The authors declare no competing financial or personal interests.

This paper has been peer-reviewed.

\section{References}

1. Gnessin E, Mandeville JA, Lingeman JE. An update on holmium laser enucleation of the prostate and why it has stood the test of time. Curr Opin Urol 2011;21:31-5. http://dx.doi.org/10.1097/ MOU.0b013e32834120d7

2. Baazeem AS, Elmansy HM, Elhilali MM. Holmium laser enucleation of the prostate: Modified technical aspects. BJU Int 2010;105:584-5. http://dx.doi.org/10.1111/j.1464-410X.2009.09111.x

3. Rausch S, Heider T, Bedke J, et al. Analysis of early morbidity and functional outcome of thulium: yttrium-aluminum-garnet laser enucleation for benign prostate enlargement: Patient age and prostate size determine adverse surgical outcome. Urology 2015;85:182-8. http://dx.doi.org/10.1016/i. urology.2014.10.002
4. Brunken C, Seitz C, Tauber S, et al. Transurethral Greenlight laser enucleation of the prostate-a feasibility study. J Endouro/ 2011;25:1199-201. http://dx.doi.org/10.1089/end.2010.0550

5. Geavlete B, Stanescu F, lacoboaie C, et al. Bipolar plasma enucleation of the prostate vs open prostatectomy in large benign prostatic hyperplasia cases - a medium term, prospective, randomized comparison. BJU Int 2013;111:793-803. http://dx.doi.org/10.1111/i.1464-410X.2012.11730.x

6. Gross AJ, Netsch C, Knipper $S$, et al. Complications and early postoperative outcome in 1080 patients after thulium vapoenucleation of the prostate: Results at a single institution. Eur Urol 2013;63:859-67. http://dx.doi.org/10.1016/i.eururo.2012.11.048

7. Sauer JS, Greenwald RJ, Bovard MA, et al. Morcellator. US Patent 5562694. Issue date: Oct 8, 1996.

8. Hochreiter WW, Thalmann $\mathrm{GN}$, Burkhard $\mathrm{FC}$, et al. Holmium laser enucleation of the prostate combined with electrocautery resection: the mushroom technique. J Urol 2002;168:1470-4. http://dx.doi. org/10.1016/S0022-5347(05)64476-X

9. Yu XX, Zhang RM, Zhou DQ, et al. Transurethral plasmakinetic enucleation of prostate and suprapubic small cut in the treatment of high risk and senior patient with benign prostatic hyperplasia and bladder stones [in Chinese]. Zhonghua yi xue za zhi 2013;93:597-9.

10. Elshal AM, Elmansy HM, Elhilali MM. Feasibility of holmium laser enucleation of the prostate (HoLEP) for recurrent/ residual benign prostate hyperplasia (BPH). BJU Int 2012;110:E845-50. http://dx.doi. org/10.1111/i.1464-410X.2012.11290.x

11. Jaeger $C D$, Krambeck AE. Holmium laser enucleation of the prostate for persistent lower urinary tract Symptoms after prior benign prostatic hyperplasia surgery. Urology 2013;81:1025-9. http://dx.doi. org/10.1016/j.urology.2013.01.019

12. Krambeck AE, Handa SE, Lingeman JE. Experience with more than 1,000 holmium laser prostate enucleations for benign prostatic hyperplasia. J Urol 2010;183:1105-9. http://dx.doi.org/10.1016/i. juro.2009.11.034

13. Wisenbaugh ES, Nunez-Nateras R, Mmeje $\mathrm{C}$, et al. Does prostate morphology affect outcomes after holmium laser enucleation? Urology 2013;81:844-8. http://dx.doi.org/10.1016/i.urology.2013.01.006

14. Placer J, Gelabert-Mas A, Vallmanya $F$, et al. Holmium laser enucleation of prostate: Outcome and complications of self-taught learning curve. Urology 2009;73:1042-8. http://dx.doi.org/10.1016/i. urology.2008.12.052

15. Abdel-Hakim AM, Habib El, El-Feel AS, et al. Holmium laser enucleation of the prostate: Initial report of the first 230 Egyptian cases performed in a single center. Urology 2010;76:448-52. http://dx.doi. org/10.1016/j.urology.2009.12.035

16. Kuntz RM, Lehrich K. Transurethral holmium laser enucleation versus transvesical open enucleation for prostate adenoma greater than $100 \mathrm{gm}$ : A randomized prospective trial of 120 patients. J Urol 2002;168:1465-9. http://dx.doi.org/10.1016/S0022-5347(05)64475-8

17. Kuntz RM, Ahyai S, Lehrich K, et al. Transurethral holmium laser enucleation of the prostate versus transurethral electrocautery resection of the prostate: A randomized prospective trial in 200 patients. J Urol 2004;172:1012-6. http://dx.doi.org/10.1097/01.ju.0000136218.11998.9e

18. Vavassori I, Valenti S, Naspro $R$, et al. Three-year outcome following holmium laser enucleation of the prostate combined with mechanical morcellation in 330 consecutive patients. Eur Urol 2008;53:599-604. http://dx.doi.org/10.1016/i.eururo.2007.10.059

19. Zhang $F$, Shao $Q$, Herrmann TR, et al. Thulium laser versus holmium laser transurethral enucleation of the prostate: 18-month follow-up data of a single center. Urology 2012;79:869-74. http://dx.doi. org/10.1016/i.urology.2011.12.018

20. Hruby $S$, Sieberer $M, S c h a t z T$, et al. Eraser laser enucleation of the prostate: Technique and results. Eur Urol 2013;63:341-6. http://dx.doi.org/10.1016/i.eururo.2012.08.049

21. Chen S, Zhu L, Cai J, et al. Plasmakinetic enucleation of the prostate compared with open prostatectomy for prostates larger than 100 grams: A randomized noninferiority controlled trial with long-term results at 6 years. Eur Urol 2014;66:284-91. http://dx.doi.org/10.1016/i.eururo.2014.01.010

22. Luo YH, Shen JH, Guan RY, et al. Plasmakinetic enucleation of the prostate vs plasmakinetic resection of the prostate for benign prostatic hyperplasia: Comparison of outcomes according to prostate size in 310 patients. Urology 2014;84:904-10. http://dx.doi.org/10.1016/j.urology.2014.06.025

23. Rao JM, Yang JR, Ren YX, et al. Plasmakinetic enucleation of the prostate versus transvesical open prostatectomy for benign prostatic hyperplasia $>80 \mathrm{~mL}$ : 12-month follow-up results of a randomized clinical trial. Urology 2013;82:176-81. http://dx.doi.org/10.1016/i.urology.2013.02.032

24. Zhao $Z$, Zeng $G$, Zhong $W$, et al. A prospective, randomised trial comparing plasmakinetic enucleation to standard transurethral resection of the prostate for symptomatic benign prostatic hyperplasia: Threeyear follow-up results. Eur Urol 2010;58:752-8. http://dx.doi.org/10.1016/i.eururo.2010.08.026

25. Zhu $L$, Chen $S$, Yang $S$, et al. Electrosurgical enucleation versus bipolar transurethral resection for prostates larger than $70 \mathrm{ml}$ : A prospective, randomized trial with 5-year followup. J Urol 2013;189:1427-31. http://dx.doi.org/10.1016/i.juro.2012.10.117

26. Liao N, Yu J. A study comparing plasmakinetic enucleation with bipolar plasmakinetic resection of the prostate for benign prostatic hyperplasia. J Endourol 2012;26:884-8. http://dx.doi.org/10.1089/ end.2011.0358 
27. Lee SH, Choi Il, Moon KY, et al. Holmium laser enucleation of the prostate: Modified morcellation technique and results. Korean J Urol 2012;53:779-84. http://dx.doi.org/10.4111/kju.2012.53.11.779

28. Bae J, Oh SJ, Paick IS. The learning curve for holmium laser enucleation of the prostate: A single-center experience. Korean J Urol 2010;51:688-93. http://dx.doi.org/10.4111/kju.2010.51.10.688

29. Ritter $M$, Krombach $P$, Bolenz C, et al. Standardized comparison of prostate morcellators using a new ex-vivo model. J Endourol 2012;26:697-700. http://dx.doi.org/10.1089/end.2011.0536
30. Cornu JN, Terrasa JB, Lukacs B. Ex vivo comparison of available morcellation devices during holmium laser enucleation of the prostate through objective parameters. J Endoruol 2014;28:1237-40. http:// dx.doi.org/10.1089/end.2011.0454

Correspondence: Dr. Ahmed M. Elshal, Urology and Nephrology Center, Mansoura University, Mansoura, Dakahlia Governorate, Egypt; elshalam@hotmail.com 